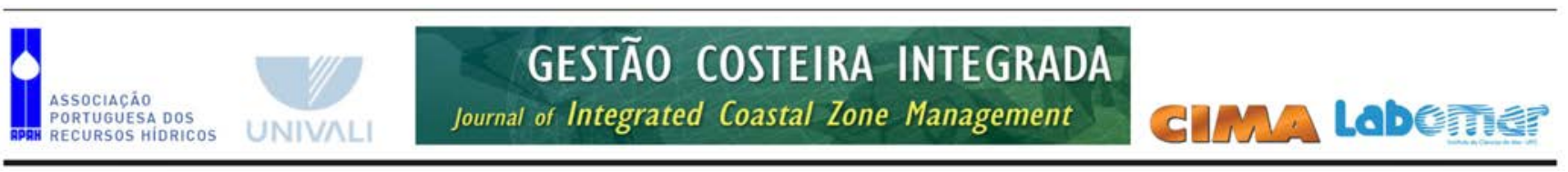

http://www.aprh.pt/rgci/pdf/rgci-482_Araujo.pdf

DOI: $10.5894 /$ rgci482

\title{
Pescadores Artesanais e pressão imobiliária urbana: Qual o destino dessas comunidades tradicionais? *
}

\section{Artisanal Fishermen and urban real estate pressure: What is the destiny of these traditional communities?}

\author{
Ismael Xavier de Araújo ${ }^{@, ~}{ }^{1}$; Roberto Sassi ${ }^{2}$; Eduardo Rodrigues Viana de Lima ${ }^{1,3}$
}

\begin{abstract}
RESUMO
Este trabalho surge da necessidade de se lançar outros olhares científicos para analisar as comunidades tradicionais de pescadores artesanais, nesse caso, do Litoral Paraibano, Nordeste do Brasil, que já não são mais camponesas, mas que, em parte, ainda possuem vínculos com a pesca, de forma direta ou indireta. Nessas comunidades de pescadores artesanais, a pesca, para muitos, já não se apresenta como atividade econômica principal, e sim secundária, ou até esporádica. A diminuição na quantidade de pescados por causa da sobrepesca e da degradação ambiental, como também o processo de urbanização do Litoral Paraibano, inserido no contexto nacional brasileiro, geram pressão imobiliária sobre as comunidades tradicionais e as modificam. Esses são fatores a serem considerados para se diagnosticar os problemas existentes e tentar apontar possíveis soluções e estratégias de ação, seja pelo Poder Público ou por organizações não governamentais. O objetivo deste trabalho é analisar o processo de urbanização e a pressão imobiliária sobre as comunidades tradicionais de pescadores artesanais nas Praias da Penha e Tambaú, no município de João Pessoa, e em Praia de Lucena, em município homônimo. Em Tambaú e Lucena, a pressão imobiliária urbana sobre as comunidades tradicionais de pescadores artesanais começou na década de 1970 . Na praia da Penha, esse processo está ocorrendo na atualidade. Para este trabalho, é adotado o materialismo histórico como método de interpretação da realidade, e a pesquisa participante como método de pesquisa, dentro de uma abordagem qualitativa. Como procedimento de pesquisa, é utilizada a pesquisa em profundidade. Isso implica em dialogar de forma mais extensa com algumas pessoas consideradas relevantes, por suas atividades e seu comprometimento com a atividade pesqueira. Por ser um trabalho de geografia urbana, a pergunta central dos diálogos desenvolvidos nesse tipo de entrevista foi: Como o processo de urbanização vem modificando as comunidades tradicionais de pesca? Os assuntos que fomentaram a discussão foram: Processo de urbanização e mudanças no cotidiano dos pescadores artesanais; Pressão imobiliária em comunidades tradicionais; Desenvolvimento local integrado como possibilidade de permanência da comunidade, ou seja, de não expropriação do espaço geográfico pelo capital; E ainda algumas possibilidades postas numa lógica de diálogo com o tema planejamento urbano, a fim de provocar a discussão na busca da totalidade. As respostas dadas pelos pescadores são sempre muito parecidas, ou até mesmo iguais, pois todos vivem ou vivenciaram o processo de urbanização de suas comunidades pesqueiras. Isso ocasionou mudanças para os/nos pescadores, com relação à moradia e ao interesse sobre onde e em que trabalhar. A incredulidade dos pescadores na melhoria das condições de trabalho e na qualidade de vida contribui para que esses profissionais não queiram que seus filhos sigam a profissão dos pais. Dizem os pescadores que o mar é perigoso; que é melhor para os filhos estudarem e se qualificarem em profissões disponíveis no espaço urbano, em que agora estão inseridos. Segundo os pescadores entrevistados, o saldo desse descontentamento é a diminuição, em cerca de $66 \%$, do número de

\footnotetext{
(a) Corresponding author: <araujoismael@hotmail.com>

${ }^{1}$ Universidade Federal da Paraíba, Programa de Pós-Graduação Geografia - PPGG (Doutorado), Centro de Ciências Exatas e da Natureza. Cidade Universitária - Campus I, 58059-900 João Pessoa, PB, Brasil. e-mail: <araujoismael@hotmail.com>

${ }^{2}$ Universidade Federal da Paraíba, Departamento de Sistemática e Ecologia, Centro de Ciências Exatas e da Natureza. Cidade Universitária - Campus I, 58051-900 João Pessoa, PB, Brasil. e-mail: <sassi_rs@yahoo.com.br>

${ }^{3}$ Universidade Federal da Paraíba, Departamento de Geografia, Centro de Ciências Exatas e da Natureza. Cidade Universitária - Campus I, 58059-900 João Pessoa, PB, Brasil. e-mail: <eduvianalima@gmail.com>
}

* Submission: 3 JAN 2014; Peer review: 12 FEB 2014; Revised: 28 APR 2014; Accepted: 24 JUN 2014; Available on-line: 14 SET 2014 
pescadores profissionais nos últimos 40 anos. O mestre de pesca Manuel, da Praia de Tambaú, calcula que há 40 anos havia cerca de 60 mestres de pesca, ou seja, capitães de barcos. Atualmente, há cerca de 20 mestres. Os entrevistados reclamam que os barcos são pequenos, com cerca de apenas 08 metros. A desorganização da atividade pesqueira, a falta de fiscalização nos repasses governamentais, a falta de acesso a crédito e o analfabetismo ou semi-analfabetismo do profissional contribuem significativamente para que essa atividade produtiva seja desinteressante para os familiares dos pescadores artesanais. Ao mesmo tempo, os pescadores da praia da Penha se encontram otimistas com a chegada de condomínios residenciais e com a possibilidade de vender sua produção pesqueira aos novos vizinhos, sem a necessidade de atravessadores. Mas, com o surgimento de novos postos de trabalho, também surge o temor de serem removidos, como ocorreu em Lucena e Tambaú. Por causa do processo de desterritorialização das comunidades tradicionais de pesca artesanal no Brasil, setores da sociedade civil organizada vêm se articulando para discutir e exigir do Governo Federal a regularização e demarcação dessas comunidades. Por isso, este artigo contribui para as reflexões sobre as comunidades de pescadores artesanais, a partir de temas como espaço urbano, moradia e possibilidades de emprego e renda para os pescadores artesanais, considerando a gestão costeira a partir da lógica do desenvolvimento local integrado. Para tanto, a discussão evolui considerando aspectos inter-relacionados ao tema, como turismo, cultura, pressão imobiliária e possibilidades de permanência dos pescadores em suas comunidades tradicionais. Nesse sentido, são propostas algumas diretrizes de cunho urbano para tratar de problemas que são urbanos, pois essas comunidades tradicionais, atualmente, estão inseridas nesse contexto. O espaço se transformou e precisa ser visto a partir de outros olhares. O esforço de desenvolver um trabalho sobre pescadores artesanais que não seja antropológico e etnográfico é motivado pelo interesse de ver profissionais de diversos campos do conhecimento se debruçando sobre essa temática que é significativa para a segurança alimentar de um país. O Brasil é um país com mais de 15 mil dispositivos legais (leis) desconhecidos pelo povo. Também possui quantidade elevada de ministérios federais (39 ministérios) e secretarias estaduais e municipais, geralmente desarticulados entre si e entre as colônias de pesca e associações de pescadores. Essa desorganização contribui apenas para os interesses econômicos de poucas pessoas, que se beneficiam desse suposto caos. Nesse cenário, há as comunidades tradicionais, muito pobres, e um sistema econômico capitalista agressivo. É nesse espaço de contradições socioespaciais que o pescador tradicional se encontra, marginalizado socialmente, economicamente e espacialmente. A Gestão Costeira Integrada deve considerar o processo de urbanização sobre as comunidades tradicionais de pescadores artesanais, pois o afastamento desses trabalhadores das praias, como também a não valorização da atividade pesqueira e de sua complexidade cultural, contribuem para a diminuição do número e da qualidade desses profissionais, relevantes para a segurança alimentar. Nessa perspectiva, a análise das comunidades de pescadores tradicionais deve contemplar estudos sobre equipamentos urbanos e instrumentos de política urbana significativos para os pescadores, que venham assegurar a visibilidade e a permanência desses trabalhadores em seus espaços geográficos.

Palavras-chave: processo de urbanização; moradia; planejamento urbano; pesca artesanal; desenvolvimento local integrado.

\section{ABSTRACT}

This work emerges from the need of analyzing the traditional communities of artisanal fishermen with other scientific eyes, more specifically on the coast of Paraiba, northeast of Brazil, which are no longer rustic, but in part, they still have direct or indirect ties with fishing. In these communities of artisanal fishermen, the fishing activity for many is no longer the main economic activity but a secondary or even a sporadic one. The decrease in the amount of fish caused by the overfishing and by the environmental deterioration as well as by the process of urbanization of the coast of Paraiba, inserted in the national Brazilian context, generate real estate pressure on the traditional communities and end up modifying them. These are factors that have to be considered to diagnose the existing problems and to try to identify the possible solutions and action strategies, be it through the government or non-governmental organizations. The objective of this work is to analyze the urbanization process and the real estate pressure on the traditional communities of artisanal fishermen at the following beaches: Praia da Penha and Tambaú, in the municipality of João Pessoa and in Praia de Lucena in the same municipality. In Tambaú and in Lucena the urban real state pressure on the traditional communities of artisanal fishermen started in the 1970s. In Praia da Penha this process is happening currently. The historical materialism was adopted as a method of reality interpretation and the participatory research was chosen as a research method, being part of a qualitative approach for this work. The in-depth research is used as a research procedure. This implies having a more extensive dialogue with some people considered to be more relevant because of their activities and commitment to the fishing activity. For being a work of urban geography, the central question of the developed dialogues in this method of interview was: how has the urbanization process been modifying the traditional fishing communities? The topics that promoted the discussion were: the urbanization process and the changes of the artisanal fishermen's daily routine; the real estate pressure on the traditional communities; integrated local development as a possibility for the community to remain where they live, in other words, of not expropriating the geographical space by capital; and also some possibilities posed in a dialogue with the urban planning theme, in order to promote a discussion in search of the wholeness. The answers given by the fishermen are always very alike, or even the same, because all of them are experiencing or experienced the urbanization process of their fishing communities. This caused changes to the fishermen in relation to housing and the interest in where to work and what to work on. The disbelief of the fishermen in improvements of work conditions and in life quality contributes for these professionals not to want their children to follow their parents' profession. The fishermen say that the sea is dangerous; that it is better for their children to study and qualify themselves for jobs available in the urban space, in which they are now inserted. According to the fishermen interviewed, the result of this discontentment is the decrease in approximately $66 \%$ of the number of professional fishermen 
over the last 40 years. The master fisher Manuel, of Praia de Tambaú, reckons that 40 years ago there were around 60 master fishers or boat captains. Currently there are approximately 20 masters. The interviewees complain about the boats being small, with only around 08 meters; the disorganization of the fishing activity, the lack of supervision on the allocation of government resources, the lack of access to credit and the illiteracy or semi-illiteracy of this professional contribute significantly for this economic activity to become uninteresting for the relatives of the artisanal fishermen. At the same time, the fishermen from the beach of Penha find themselves optimistic with the arrival of residential condominiums and with the possibility to sell their fisheries production to the new neighbors without the need of middlemen. However, with the arrival of new jobs, the fear of being removed, as it happened in Lucena and in Tambaú, also emerges. Because of the deterritorialization process of the traditional communities of artisanal fishing in Brazil, sectors of the organized civil society have been articulating themselves to discuss and demand from the federal government the regularization and demarcation of these communities. Therefore, this article contributes to reflections about the communities of artisanal fishermen as regards to themes such as urban space, housing and job possibilities and income for the artisanal fishermen, considering the coastal management from the logic of integrated local development. For that reason, the discussion evolves considering aspects that are interrelated to the theme, such as tourism, culture, real estate pressure and possibilities of the fishermen to remain in their traditional communities. Accordingly, some urban guidelines are proposed to address problems that are urban, because these traditional communities currently are inserted in this context. The space was transformed and needs to be seen from other eyes. The effort of developing a work about artisanal fishermen that does not have an anthropologic or ethnographic nature is motivated by the interest of seeing professionals of several fields of knowledge addressing to this theme which is significant for the food safety of a country. Brazil is a country with more than 15 thousand laws, unknown by its people. It also has a high quantity of federal ministries (39 ministries) as well as state and municipal departments, which are generally not articulated amongst themselves and neither among the fishery colonies and fishermen associations. This disorganization only contributes to the economic interests of few people that benefit themselves from this supposed chaos. In this scenario, there are the very poor traditional communities and an aggressive capitalist economic system. It is in this scope of social and spatial contradictions that the traditional fisherman finds himself, socially, economically and spatially marginalized. The Integrated Coastal Management should consider the urbanization process on the traditional communities of artisanal fishermen, because the distancing of these workers from the beaches as well as the non valuing of the fishing activity and of its cultural complexity contribute to the decrease of the number and of the quality of these professionals, who are relevant for the food safety. Under this perspective, the analysis of the traditional fishermen communities should contemplate significant studies on urban facilities and urban policy instruments for the fishermen, which will ensure the visibility and persistence of these workers in their geographic spaces.

Keywords: urbanization process; housing; urban planning; artisanal fishing; integrated local development.

\section{Introdução}

A atividade pesqueira tradicional proporciona emprego para mais de $90 \%$ dos pescadores de captura do mundo, e sua importância para a segurança alimentar e para a mitigação e prevenção da pobreza vem sendo cada vez mais estudada. Todavia, a falta de capacidade institucional e a não inclusão do setor em políticas de desenvolvimento nacionais e regionais limitam a possibilidade de contribuição dessa atividade econômica (Mathiesen, 2012).

A pesca compreende uma atividade de recolecção através da exploração dos recursos biológicos da hidrosfera, considerando os componentes biológicos aquáticos, o meio físico-químico aí existente e a sociedade, recolectando ou predando (Lackey \& Nielsen, 1980). De forma artesanal, a pesca tem como objetivo uma grande variedade de espécies de peixes, moluscos e crustáceos. Para captura, são usadas diferentes artes de pesca. Geralmente, a atividade ocorre em zonas próximas à costa, de pouca profundidade. As embarcações utilizadas são de pequeno e médio porte, tripuladas geralmente por até três pessoas (Urbistondo, 2001), que compreendem o capitão da embarcação, denominado mestre, e dois ajudantes, que podem ser aprendizes ou mesmo profissionais.
A Lei Federal brasileira $n^{0} 11.959 / 2009$, que estabelece a Política Nacional de Desenvolvimento Sustentável da Aquicultura e da Pesca, define pesca como toda a operação, ação ou ato tendente a extrair, colher, apanhar, aprender ou capturar recursos pesqueiros. Por sua vez, recursos pesqueiros são os animais e vegetais hidróbios passíveis de exploração, estudo ou pesquisa pela pesca amadora, de subsistência, científica, comercial e pela aquicultura. Ainda de acordo com esse dispositivo legal, pescador artesanal é o trabalhador que pratica diretamente a pesca profissional, de forma autonoma ou em regime de economia familiar, com meios de produção próprios ou mediante contrato de parceria, podendo utilizar embarcações de pequeno porte.

Nesse tipo de atividade extrativista voltada para o comércio, em que o pescado geralmente é repassado para um intermediário, a acumulação de capital praticamente inexiste, de maneira que a pobreza, a baixa escolaridade e a falta de financiamentos públicos e privados são características marcantes no perfil dos trabalhadores que atuam nessa atividade do setor primário da economia.

Isso também implica em moradias de baixo padrão de renda, tornando-os mais vulneráveis à remoção pelo Poder Público ou compra da casa por pessoas com 
poder aquisitivo elevado ou grupos econômicos que se interessem pelo espaço litorâneo que os pescadores estejam ocupando, no sentido da apropriação do capital, que, atualmente, compreende a construção de condomínios residenciais fechados ou de lazer, hotéis, resorts, restaurantes, dentre outros equipamentos urbanos que interessam ao capital.

A literatura científica sobre os pescadores artesanais os classifica como camponeses e trabalhadores do mar. Também surgem textos que mostram os pescadores artesanais como apenas trabalhadores do mar. Na pesca artesanal brasileira, a única evolução marcante nas últimas décadas foi na utilização da embarcação, que avançou de jangada e barco a vela para barco a motor, na década de 1960, o que contribuiu para o aumento da produção do pescado e para uma maior mobilidade do pescador. O que é escasso na literatura sobre pescadores artesanais é uma discussão sobre sua situação de moradia quando do avanço da urbanização sobre essas comunidades tradicionais, bem como proposições a esse respeito.

Nos últimos 40 anos, o crescimento urbano acelerado das cidades brasileiras vem alcançando e englobando muitas comunidades de pescadores, transformando o rural em urbano. Isso demanda novas formas de entender a complexidade dessa atividade econômica e, ainda mais relevante, a complexidade do modelo de interpretação dessa realidade, considerando as mudanças na forma e função dessas comunidades tradicionais, o que contribui para proposições que venham analisar o tema 'pescadores artesanais', de maneira mais específica, ou seja, mais direcionada para as suas realidades atuais.

Discutir sobre pesca e pescador artesanal se justifica por se saber que, no Brasil, a pesca artesanal é responsável por $45 \%$ da produção de pescado do país, além de empregar $98 \%$ dos pescadores do país, com importante contribuição na soberania alimentar. Além disso, garante a renda de mais de um milhão de famílias.

Há muitos espaços geográficos que ainda formam comunidades tradicionais, compondo espaços de moradia, de trabalho e de vida, reproduzindo relações sociais, culturais e econômicas que precisam, além de ser investigadas e diagnosticadas, ser também levadas à discussão no plano de estratégias de ação municipal, a fim de fazer frente ao processo de modificação do lugar de trabalho e de vida que prejudique a reprodução do trabalhador pescador e de seu cotidiano, o que implica, também, analisar o processo de mudanças nos padrões de geração de emprego e renda da comunidade, como também do espaço de moradia, à medida que o urbano $\mathrm{e}$ a especulação imobiliária passam a compor o cotidiano.

Este texto segue o seguinte raciocínio: entender como o processo de urbanização brasileira modificou e vem modificando o cotidiano de comunidades de pescadores artesanais; entender o porquê da pressão urbana sobre essas comunidades; para daí, então, poder sugerir algumas diretrizes que venham se desdobrar em estratégias de ação de acordo com os dados até aqui coletados e os argumentos até então postos, considerando as falas de sujeitos sociais que vivenciam as realidades dessas praias.

\section{Objetivos}

\subsection{Geral}

Analisar o processo de urbanização e a pressão imobiliária sobre as comunidades tradicionais de pescadores artesanais nas Praias da Penha e Tambaú, em João Pessoa, e em Praia de Lucena, em município homônimo.

\subsection{Específicos}

- Entender como o processo de urbanização brasileira modificou e vem modificando o cotidiano de comunidades de pescadores artesanais;

- Compreender os motivos da pressão urbana sobre essas comunidades tradicionais;

- Abordar diretrizes que venham se desdobrar em estratégias de ação para a permanência das comunidades tradicionais, frente ao capital imobiliário.

\section{Caracterização das áreas}

Para entender os novos padrões espaciais de algumas comunidades de pescadores e, também, suas novas relações de trabalho e mudanças no cotidiano, neste estudo, foram analisadas três comunidades de pescadores: A comunidade de pescadores artesanais da Praia da Penha, localizada no setor Leste da Cidade de João Pessoa / PB, inserida no polo turístico do município; a comunidade de pescadores artesanais que residia na Praia de Tambaú, praia urbana mais frequentada da cidade de João Pessoa; e a comunidade de pescadores artesanais que residia na praia central da cidade de Lucena/PB, cidade esta situada ao norte do município de João Pessoa.

As distâncias em relação ao Centro da Cidade de João Pessoa, capital da Paraíba, são: Praia da Penha - 14km; Praia de Tambaú - 07km; Praia de Lucena - 25km.

As coordenadas geográficas decimais da Sede do município de João Pessoa são: Latitude -7.11532 e longitude -34.861; e da Sede do município de Lucena são: Latitude -6.89927 e longitude -34.8691.

Essas praias estão assentadas sobre formações arenosas holocênicas do último período de transgressãoregressão marinha, com altitudes de até 6 metros. Seus sedimentos são formados por areias quartzosas finas. $\mathrm{O}$ clima é Tropical Litorâneo Úmido, com chuvas de outono a inverno, precipitação de $1800 \mathrm{~mm} / \mathrm{ano}$ e 


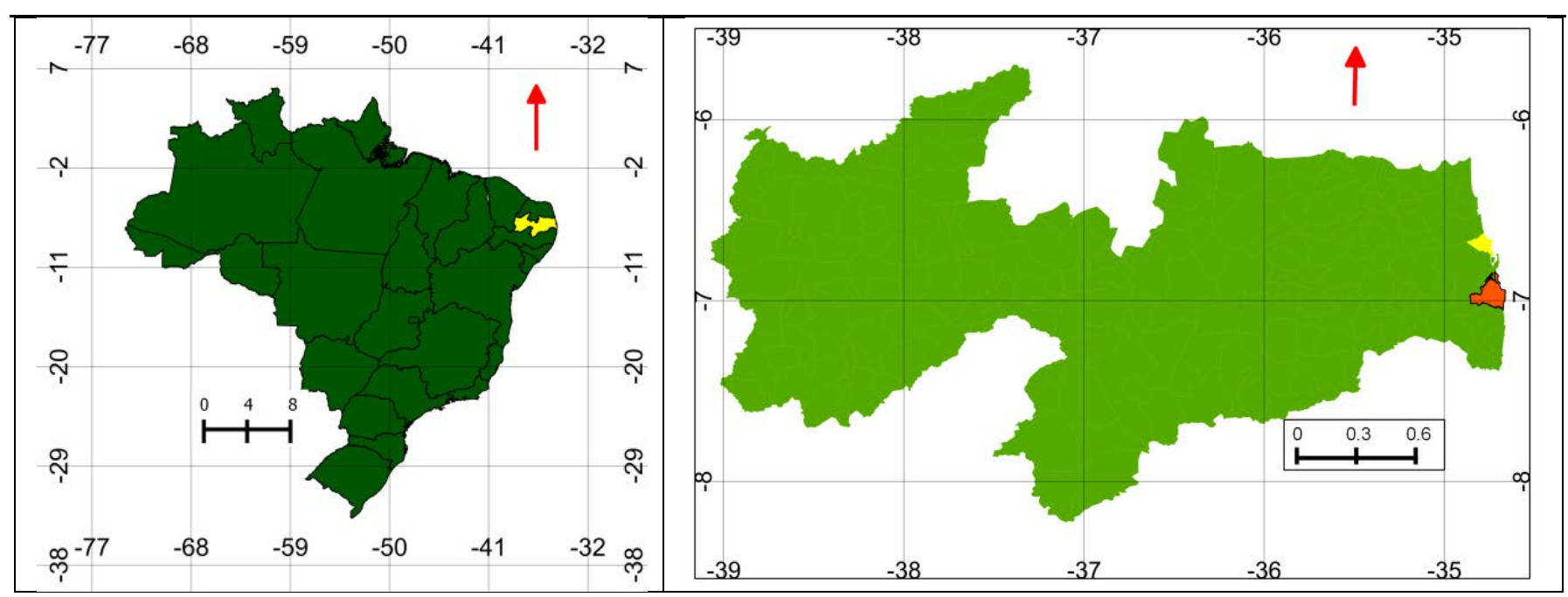

Figura 1 - Mapa de localização do estado da Paraíba em relação ao Brasil, e dos municípios de João Pessoa e Lucena em relação à Paraíba. Fonte: IBGE (2010).

Figure 1 - Location map of the state of Paraiba in relation to Brazil, and of the municipalities of João Pessoa and Lucena in relation to Paraiba. Source: IBGE (2010).

umidade relativa do ar em torno de $76 \%$. As correntes marinhas são de Sudeste-Noroeste, e a plataforma continental possui $50 \mathrm{~km}$ na costa do estado da Paraíba. Há uma linha on shore, de arrecifes de corais intermitentes e paralela à costa numa distância de $1 \mathrm{~km}$.

\section{Metodologia}

A sociedade está inserida em espaços de disputas desiguais entre grupos e classes de interesses e poderes aquisitivos diferentes e contraditórios. Por isso, a metodologia utilizada neste trabalho, quanto à forma de interpretação da realidade, é alicerçada pelo materialismo histórico, que tem como princípio a análise da realidade como produto histórico da sociedade, dado em determinadas condições postas pelos grupos socioeconômicos dominantes.

Desta feita, a abordagem é qualitativa, considerando o aprofundamento da compreensão das relações sociais dos pescadores. Com relação ao método de pesquisa, este trabalho está alicerçado na pesquisa participante, a qual tem como fundamento a análise de uma determinada realidade a partir da observação dos sujeitos da pesquisa. (Gerhardt \& Silveira, 2009).

O procedimento de pesquisa utilizado foi a Entrevista em Profundidade. A finalidade é dialogar por mais de uma vez com os sujeitos da pesquisa. Esses diálogos objetivam compreender as perspectivas que os sujeitos da pesquisa possuem a respeito de seu trabalho e de sua vida, além de experiências cotidianas. $\mathrm{O}$ começo do diálogo pode se dar por uma afirmação, uma pergunta, uma interjeição etc., sem haver uma estruturação de perguntas e respostas, o que contribui para que o pesquisador possa adquirir mais conhecimentos sobre o espaço pesquisado e as pessoas que o animam (Taylor \& Bogdan, 2008).
Os diálogos com os sujeitos da pesquisa começaram a partir da seguinte pergunta: como as casas de veraneio e os condomínios residenciais de luxo vêm modificando as comunidades tradicionais de pesca?

A partir dessa pergunta, feita para os entrevistados, os diálogos produziram dados semelhantes no discurso de cada um. Daí em diante, sendo as respostas dos sujeitos da pesquisa muito parecidas, se fazia outra pergunta que também foi feita em todos os diálogos: Qual seria a solução para garantir que os pescadores atuais continuassem trabalhando e tendo renda a partir da pesca?

\section{Processo de urbanização e mudanças no cotidiano dos pescadores artesanais}

Com o avanço das cidades, muitas comunidades tradicionais, como, por exemplo, de pescadores, foram englobadas pela malha urbana, implicando na remoção de comunidades de pescadores, ou até mesmo sua pulverização, dispersão na cidade, causada pela relocação encampada por pessoas que se diziam donas de faixas litorâneas, destinando os terrenos onde ficavam as moradias dos pescadores para o loteamento imobiliário voltado para as casas de veraneio. Esse fenômeno foi bastante representativo no litoral Paraíbano a partir da década de 1970.

Com isso, a atividade pesqueira ainda continuou sendo a ocupação de muitos trabalhadores, mas, a partir daí, muitos pescadores se viram em uma nova condição, a de moradores urbanos. Nesse caso, em duas situações distintas, ou morando em casas localizadas a alguns quarteirões do mar, ou pior, residindo em aglomerados de moradias subnormais, termo mais conhecido no Brasil por comunidades ou favelas, ou mesmo, em muitos casos, nas duas condições ao mesmo tempo. 
Dessa forma, padrões de moradias seculares deixam de existir em meses para dar lugar a outra estrutura, a outro ritmo, trazendo consigo novas características de vida no que se torna urbano. Em vários casos, o único padrão que se aprofunda é a pobreza, além da negação pelo capital de o trabalhador permanecer morando na praia e ter a possibilidade de, num futuro próximo, serem o pescador e sua família orientados por empresários que poderiam ser parceiros, ou mesmo o Poder Público, a diversificar sua fonte de renda com atividades voltadas ao turismo e à cultura, como parte integrante de uma comunidade tradicional, por isso diferenciada, oferecendo serviços culturais diferenciados em relação ao que os grandes equipamentos turísticos propiciam.

Os grandes equipamentos turísticos geralmente propiciam o chamado não-lugar. Este é caracterizado pela ausência de diferenciação histórica e cultural em relação aos espaços ao redor, portanto sem identidade. $\mathrm{O}$ não-lugar é desprovido de um contexto local e geralmente segue padrões arquitetônicos internacionais, descontextualizados da localidade em que está inserido. Tudo isso em oposição ao lugar, espaço histórico, cultural, onde há relação de identidade entre os habitantes e o ambiente.

Quanto ao campo, é esse um lugar de produção e de obras. A produção agrícola/pesqueira faz nascerem produtos; a paisagem é uma obra. Essa obra emerge de um espaço lentamente modelado, originariamente ligado aos grupos que a ocupam através de uma recíproca sacralização que é a seguir profanada pela cidade e pela vida urbana, que captam essa sacralização, condensam-na e depois a dissolvem no transcorrer das épocas, absorvendo-a na racionalidade (Lefebvre, 2001).

Essa sacralização é aqui entendida como relação de respeito e ética por parte do pescador com o ambiente de praia e com o mar, como também com sua comunidade, que vai se modificando a ponto de se transformar de forma complexa a partir dos novos arranjos espaciais e culturais do espaço urbano, de moradia e até mesmo de localização e distância, que são submetidos pelos grupos econômicos, que buscam ocupar os espaços que antes eram do pescador, chegando ao ponto de famílias de pescadores virem a não se interessar mais por este ofício.

Nesse sentido, o próprio Poder Público torna-se criador privilegiado de escassez, ou seja, contribui para tornar os espaços mais caros e cobiçados, estimulando a especulação e fomentando a produção de espaços vazios dentro das cidades (Santos, 2008), o que contribui para que o capital pressione as comunidades tradicionais de pesca, ou seja, através da força do setor imobiliário, pelo encantamento do pescador no sentido de vender a sua casa e ir morar em áreas mais afastadas da costa, o que irá prejudicá-lo quanto às potencia- lidades de sua atividade junto a outras atividades econômicas, como turismo, serviços culturais, dentre outros.

Assim, o pescador, transformado em morador urbano, passa a assumir posições diferenciadas nas formas de pensar e agir, pois o modelo espacial que passa a existir ao seu redor e dentro de sua comunidade, a saber, o urbano, muda seu cotidiano e, até mesmo, contribui para direcioná-lo a trabalhar em outras atividades econômicas, pois estas passam a se multiplicar no novo cenário socioeconômico de moradia. Desta feita, essa vida urbana, com sua poluição e ocupações irregulares em áreas ambientalmente impróprias, prejudica a produção pesqueira, o que impele o pescador e seus filhos para outras atividades econômicas, em que a pesca, em muitos casos, passa a ser atividade econômica secundária, e não mais principal, o que vai afastando do ofício as gerações seguintes.

Com a mudança nos padrões espaciais e a complexidade das novas possibilidades de trabalho, as necessidades dos indivíduos da comunidade tradicional se multiplicam, surgindo necessidades criadas, ou seja, que não são básicas, como é primordial comer, beber, morar, dormir bem, dentre outras. As necessidades criadas trazem desejos de possuir melhores roupas, calçados, veículos, eletroeletrônicos etc. Daí o interesse por outras fontes de renda, que passam a concorrer com a pesca, o que consiste no fetiche da mercadoria.

Segundo Marx (1996), o fetiche da mercadoria é a relação social entre os próprios homens, que, para eles, aqui assume a forma fantasmagórica de uma relação entre coisas. Por isso, para encontrar uma analogia, temos de nos deslocar à região nebulosa do mundo da religião. Aqui, os produtos do cérebro humano parecem dotados de vida própria, figuras autônomas, que mantêm relações entre si e com os homens. Assim, o mundo das mercadorias acontece com os produtos da mão humana.

Isso Karl Marx chama de fetichismo, que adere aos produtos de trabalho, tão logo são produzidos como mercadorias, e que, por isso, é inseparável da produção de mercadorias. Esse caráter fetichista do mundo das mercadorias provém, como a análise precedente já demonstrou, do caráter social peculiar do trabalho que produz mercadorias.

Com isso, objetos de uso se tornam mercadorias apenas por serem produtos de trabalhos privados, exercidos independentemente uns dos outros. O complexo desses trabalhos privados forma o trabalho social total. Como os produtores somente entram em contato social mediante a troca de seus produtos de trabalho, as características especificamente sociais de seus trabalhos privados só aparecem dentro dessa troca.

Para tanto, o tempo de trabalho no mar, como pescador artesanal, com o decréscimo do pescado nas últimas 
décadas, não passa a ser mais tão vantajoso para o pescador que reside em área urbana, em comparação a outras atividades relacionadas ao espaço urbano, como os serviços de pintor, pedreiro, vigilante, jardineiro, caseiro, garçom etc. Assim, para consumir a mesma quantidade de produtos, ou até mais, a renda da pesca e o tempo para obtê-la se tornam desvantajosos em relação a outras atividades econômicas.

Para denominar a sociedade pós-industrial, ou seja, aquela que nasce da industrialização e a sucede, propomos, aqui, o conceito de sociedade urbana que designa, mais que um fato consumado, a tendência, a orientação, a virtualidade. Isso, por conseguinte, não tira o valor de outra caracterização crítica da realidade contemporânea, como, por exemplo, a análise da "sociedade burocrática de consumo dirigido". O tecido urbano prolifera, estende-se, corrói os resíduos de vida agrária. Essas palavras, "o tecido urbano", não designam, de maneira restrita, o domínio edificado nas cidades, mas o conjunto das manifestações do predomínio da cidade sobre o campo (Lefebvre, 1991).

Esse conjunto das manifestações do predomínio da cidade sobre o campo é percebido na diferenciação dos ritmos de trabalho e vida desses espaços diferenciados. Também são observados nos desejos de consumo, que se aguçam quando a aglomeração de pessoas é maior. No espaço urbano, a maior circulação de informação e de transportes facilita a capacidade de manobrar/ /ditar/dirigir o que a sociedade de massa deve consumir.

Essa imposição das elites para as massas implica em analisar de forma atenta quais são as mudanças que estão ocorrendo nas comunidades de pescadores artesanais que, por algum motivo, ainda estão emersas em áreas urbanas e não foram, ao menos por enquanto, relocadas de alguma maneira pela força do capital, para dar lugar a empreendimentos imobiliários. Capital este que, como criador de necessidades, dentro da lógica do fetiche da mercadoria, também cria até mesmo o interesse do pescador, desavisado ou desiludido, de sair do ambiente de praia para morar em outras partes da cidade, muitas vezes, longe do seu lugar de trabalho, o mar e a praia.

\section{Pressão imobiliária em comunidades tradicionais de pescadores artesanais}

O crescimento urbano no Brasil foi e ainda é pautado na edificação de áreas em saltos. Esses saltos obedecem à lógica da especulação imobiliária, onde há descontinuidades no processo de urbanização, a fim de que os espaços deixados vazios entre uma faixa urbana construída e outra possam valorizar com o tempo, à medida que a infraestrutura, os serviços público e privados e a circulação de pessoas e mercadorias valorizem ainda mais os vazios urbanos.

A partir da proliferação do automóvel para a classe alta e classe média alta, no final da década de 1970, em João
Pessoa, e do aumento de coletivos nas linhas de ônibus, atrelada à política habitacional de construção de conjuntos habitacionais para a população de baixa renda, no período da Ditadura Militar (1964-85), a cidade começou a se expandir rapidamente.

Esse modelo de expansão rápida ou "urban sprawl", como citado por Ojima (2007), surge em meados da década de 1960 e expressa o crescimento descontrolado das aglomerações urbanas norte-americanas, principalmente pela dispersão do padrão suburbano de urbanização. Tal processo ocorreu, nos Estados Unidos, com maior evidência no período pós-Segunda Guerra Mundial, quando a população americana de maior poder aquisitivo buscou, nas áreas mais afastadas dos centros das cidades, melhor qualidade de vida.

O termo "urban sprawl" indica crescimento exagerado da cidade, a partir de práticas como a produção de subúrbios, condomínios horizontais fechados e conjuntos habitacionais populares, localizados nas "franjas" ou bordas urbanas, distantes do centro e da mancha consolidada da cidade. (Ojima, 2007).

No caso de João Pessoa, a cidade nasceu às margens do rio Sanhauá e cresceu em direção às praias marítimas. A partir da década de 1970, as elites buscaram, nas proximidades das praias, lugares afastados das classes menos favorecidas, ao mesmo tempo em que buscaram também estabelecer moradias, num primeiro momento, de segunda residência, adensando o urbano nesses espaços.

Além de se afastarem dos despossuídos, as elites também buscavam usufruir dos ambientes naturais de praia, os quais sempre foram vistos como espaços de lazer. Nesse momento histórico, o espaço de lazer temporário passou, gradativamente, a ser espaço perene de lazer e vida, onde também era, como ainda é, relevante o contato com a natureza.

Santos (2008) afirma que a natureza, hoje, é um valor, e, em termos de processo histórico, ela é social. O valor da natureza está relacionado com a escala de valores estabelecida pela sociedade para aqueles bens que antes eram chamados naturais. Essa valorização incide de modo importante sobre as zonas costeiras dos países periféricos e tropicais. Obviamente, essas praias ensolaradas são produtos de venda fácil para quem tem poder aquisitivo, mercadorias valorizadas para as elites do país e populações dos países temperados e frios. Essa questão, na verdade, cria um potencial de desenvolvimento que pode ser um fator portador de uma multiplicação de serviços, de empregos diretos e indiretos e de circulação de mercadorias, mas que também inclui um potencial de impactos perversos, tanto ambientais como sociais, como tem sido para as comunidades tradicionais de pescadores.

O processo de urbanização, quando chega a uma comunidade de pescadores, não tira deles o caráter de comunidade tradicional. Daí a possibilidade de direcio- 
nar políticas públicas nessa perspectiva, para que os trabalhadores pescadores possam permanecer em suas moradias históricas a partir de uma releitura deles por eles mesmos, devidamente interpretada pelos pró-prios pescadores, além de técnicos e cientistas, analisando e propondo possibilidades, contando com a colaboração do Poder Público, tendo em vista a relação de desvantagem socioeconômica dessas comunidades em relação ao capital, pois este tem maior poder de articulação e reinvenção.

Para proteger as comunidades tradicionais, inclusive comunidades de pescadores, foi promulgado no Brasil o Decreto Federal n. ${ }^{\circ}$ 6.040/2007, que Institui a Política Nacional de Desenvolvimento Sustentável dos Povos e Comunidades Tradicionais, que, no art. $2^{\circ}$ de seu anexo, expressa como objetivo geral promover o desenvolvimento sustentável dos Povos e das Comunidades Tradicionais, com ênfase no reconhecimento, no fortalecimento e na garantia dos seus direitos.

Embora todas essas dimensões estejam contempladas no objetivo geral desse Decreto, que insere os pescadores artesanais como comunidade tradicional, essa lei ainda carece de atenção por parte do Poder Público, que não possui a mesma velocidade de ação dos grupos capitalistas, que reinventam formas de se apropriar das terras que interessam à acumulação de capital, de acordo com o tempo e o espaço.

Desta feita, historicamente, as comunidades de pescadores são extintas pelo capital imobiliário, através da expulsão dos pescadores da faixa de praia pelos pretensos donos de faixas litorâneas, seja pelo Estado, que reloca esses trabalhadores para áreas mais distantes da praia, seja por grupos empresariais que chegam com recursos financeiros suficientes para comprarem, Paulatinamente, a preços baixos, as moradias precárias dos pescadores.

Atualmente, é o Decreto Federal $n^{\circ}$ 6.040/2007 que surge como instrumento jurídico norteador para garantir o pescador em faixa de praia, pois considera Povos e Comunidades Tradicionais como grupos culturalmente diferenciados e que se reconhecem como tais, que possuem formas próprias de organização social, que ocupam e usam territórios e recursos naturais como condição para sua reprodução cultural, social, religiosa, ancestral e econômica, utilizando conhecimentos, inovações e práticas gerados e transmitidos pela tradição. Assim como entende que Territórios Tradicionais são os espaços necessários à reprodução cultural, social e econômica dos povos e das comunidades tradicionais, sejam eles utilizados de forma permanente ou temporária.

O reconhecimento de que há uma comunidade tradicional em ambiente de vetor de crescimento urbano contribui para que uma determinada zona rural que passa a ser urbana não seja passível de ser removida pelo capital imobiliário, que busca nos espaços litorâ- neos ambientes para sua constante reprodução, tendo em vista que a visibilidade dos povos e das comunidades tradicionais deve se expressar por meio do pleno e efetivo exercício da cidadania, considerando, dentre outros princípios, o reconhecimento e a consolidação dos direitos dos povos e das comunidades tradicionais, o que implica na permanência no território de trabalho, moradia e vida, como expressa a Política Nacional de Desenvolvimento Sustentável dos Povos e Comunidades Tradicionais.

\section{Comunidades tradicionais de Pescadores Artesanais: Praia de Lucena, Praia de Tambaú e Praia da Penha}

A problemática urbana não permite ao pensamento lançar-se na exploração do possível sem precaução. Cabe ao analista descrever e discernir tipos de urbanização e dizer no que se tornaram as formas, as funções, as estruturas urbanas transformadas pela explosão da cidade antiga e pela urbanização generalizada (Lefebvre, 1999).

Nessa perspectiva, para expressar o espaço em termos mais observáveis, podemos entender que, sempre que a sociedade (a totalidade social) sofre uma mudança, as formas ou os objetos geográficos (tanto os novos como os velhos) assumem novas funções; a mutação cria uma nova urbanização espacial. Em qualquer ponto do tempo, o modo de funcionamento da estrutura social atribui determinados valores às formas. Todavia, se examinarmos apenas uma fatia de tempo homogêneo, careceremos de um contexto em que possamos basear nossas observações, uma vez que a estrutura varia conforme os diferentes períodos históricos (Santos, 1985).

Assim, consideramos a urbanização um processo social, espacialmente fundamentado, no qual um amplo leque de sujeitos, com objetivos e compromissos diversos, interage por meio de uma configuração específica de práticas espaciais entrelaçadas. Em uma sociedade vinculada por classes, como a sociedade capitalista, essas práticas espaciais adquirem um conteúdo de classe definido, o que não quer dizer que todas as práticas espaciais possam ser assim interpretadas. Considerando ainda que, sob o capitalismo, o amplo leque das práticas de classe, em associação com a circulação do capital, a reprodução da força de trabalho e das relações de classe, e a necessidade de controlar a força de trabalho permanecem hegemônicos (Harvey, 2005).

A pressão imobiliária urbana que ocorre na Praia da Penha (Fig. 2 e 3 ) e em seus contornos acontece devido ao processo de periferização das classes mais abastadas, pois a área central (o centro da cidade), à medida que vai aumentando sua dinâmica econômica em comércio e prestação de serviços, deixa de ser confortável como 
ambiente de moradia para as classes de maior poder aquisitivo. Com isso, "A elite, a partir do momento em que se inicia o processo de centralização das atividades comerciais e prestações de serviços, começa progressivamente a abandonar suas residências centralmente localizadas, indo residir na periferia". (Corrêa, 2002).

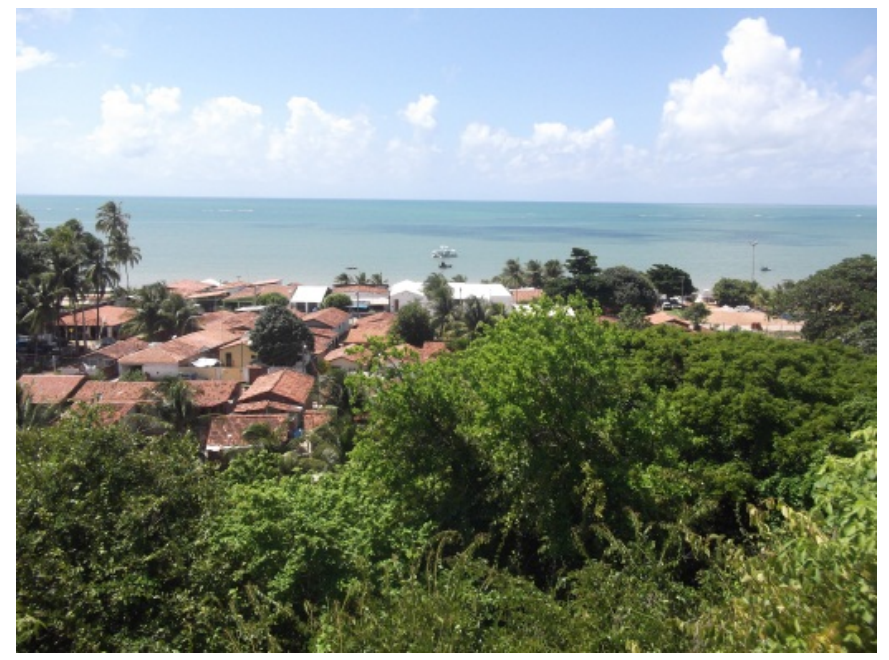

Figura 2 - Vista de parte da Comunidade de Pescadores Artesanais da Penha.

Figure 2 - View of the Artisanal Fishermen Community of Penha.

Em relação ao onde morar, é preciso lembrar que existe um diferencial espacial na localização de residências vistas em termos de conforto e qualidade. Essa diferença reflete, em primeiro lugar, um diferencial no preço da terra - que é função da renda esperada - que varia em função das amenidades e da acessibilidade (Corrêa, 2002). Além de os ambientes de amenidades serem espaços apreciados para a moradia, também o são para o lazer e o entretenimento.

As faixas de praia no Brasil, assim como em diversos países pelo mundo, são procuradas para nelas serem construídos equipamentos turísticos e de entretenimento, voltados para os mais abastados, não só da cidade e da região, mas também de qualquer lugar do planeta. Dessa forma, uma área de praia, na cultura da população litorânea do Nordeste brasileiro, implica em espaço de amenidades, ou seja, possui humidade elevada, propicia a facilidade do banho de mar, sol, espaço natural que culturalmente serve ao lazer e ao entretenimento, à atividade física e à contemplação.

Num primeiro momento, comprar moradias numa comunidade de pescadores pareceria desinteressante para o capital, mas, ao contextualizar a realidade especulativa do espaço urbano em que está inserido o Bairro da Penha e sua comunidade de pescadores, ou seja, em um espaço que já é urbano e, para além disso, zona destinada ao turismo pela Lei de Zoneamento Municipal, mostra a posição estratégica para o capital imobiliário em relação ao Bairro da Penha e sua localização.

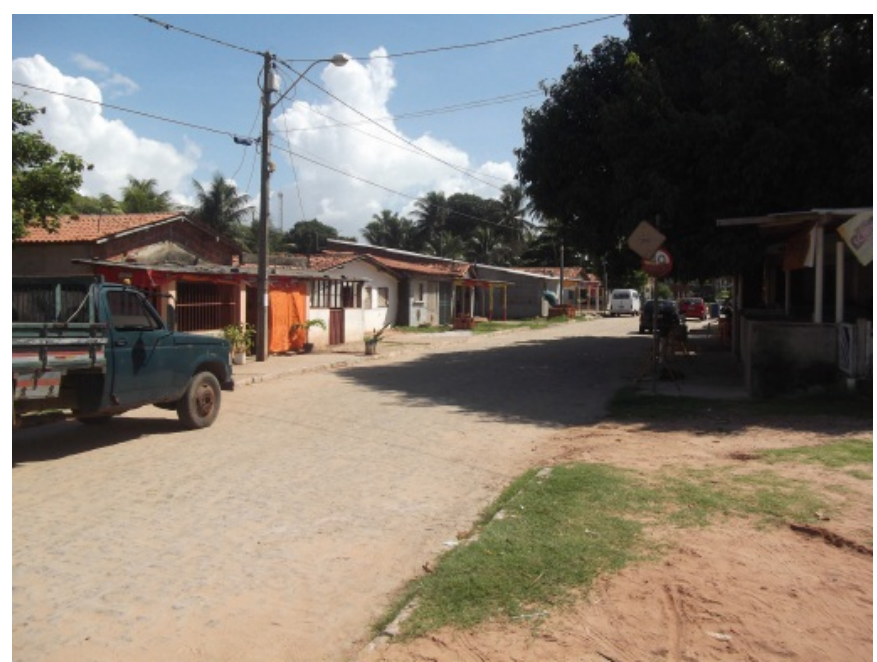

Figura 3 - Padrão das moradias dos pescadores.

Figure 3 - Fishermen housing standards.

Nesse contexto, as terras urbanas que hoje estão em posse dos pescadores caracterizariam o espaço de pior localização dessa zona costeira para se adquirir imóveis, tendo em vista que, nesse espaço, vivem pessoas de baixo poder aquisitivo, e que também os outros terrenos ao redor estão loteados para condomínios residenciais de alto padrão, hotéis e equipamentos de lazer e entretenimento, o que torna esses terrenos ao redor bem mais caros.

Todavia, é nos espaços aparentemente desinteressantes para o setor imobiliário que é possível se realizar lucros mais vultosos. A localização é sempre relativa, e, sendo assim, é possível relativizar espaços considerando suas características atraentes. Dependendo do que se venha considerar quando da valorização de uma área, aspectos como segregação socioespacial e lazer tendem a interessar pessoas abastadas, o que desperta o interesse do capital imobiliário.

Do ponto de vista comparativo com outras comunidades de pescadores do estado da Paraíba, podemos observar que a história de apropriação de comunidades de pescadores pelo capital imobiliário, como vem ocorrendo na Praia da Penha, possui características semelhantes com o que já aconteceu na década de 1970 em Tambaú, praia central de João Pessoa (Fig. 4), atualmente com sua orla ocupada por hotéis e prédios residenciais que servem a pessoas com alto poder aquisitivo.

Isso também ocorreu em Lucena, município que atualmente tem a sua orla ocupada por casas de veraneio, pousadas e loteamentos (Fig. 5). Naquele momento histórico, nos dois casos (Tambaú e Lucena), pessoas mais abastadas compraram casas e terrenos, onde moravam os pescadores, de pessoas que se consideravam donas dessas terras. O saldo social é a atual situação de moradia desses pescadores, que estão, 
em grande parte, no aglomerado de moradias subnormais São José, entre os bairros nobres de Tambaú e Manaira, em João Pessoa; e na "comunidade" Carrapeta, em Lucena.

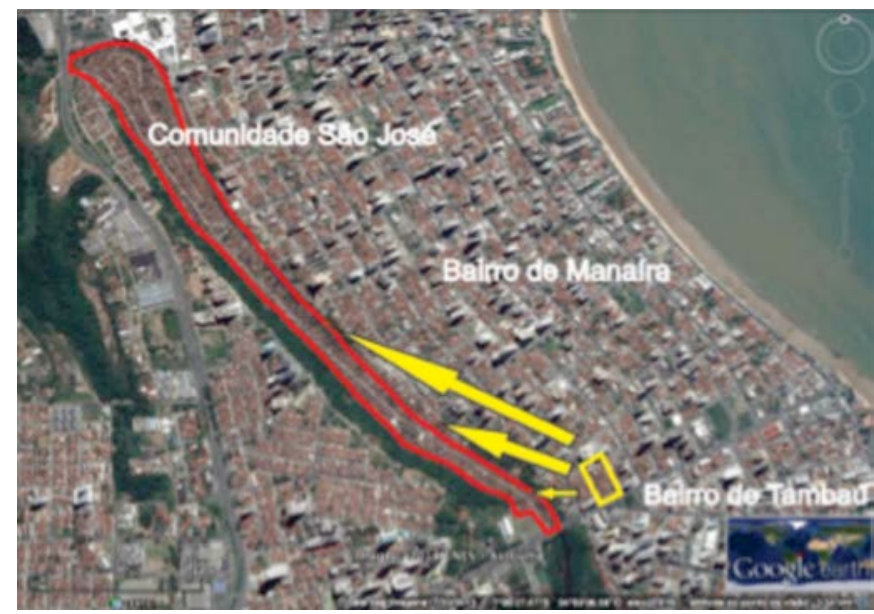

Figura 4 - Deslocamento dos pescadores de Tambaú para a comunidade subnormal São José, em João Pessoa.

Figure 4 - Movement of the fishermen of Tambau to the ghetto São José, in João Pessoa.

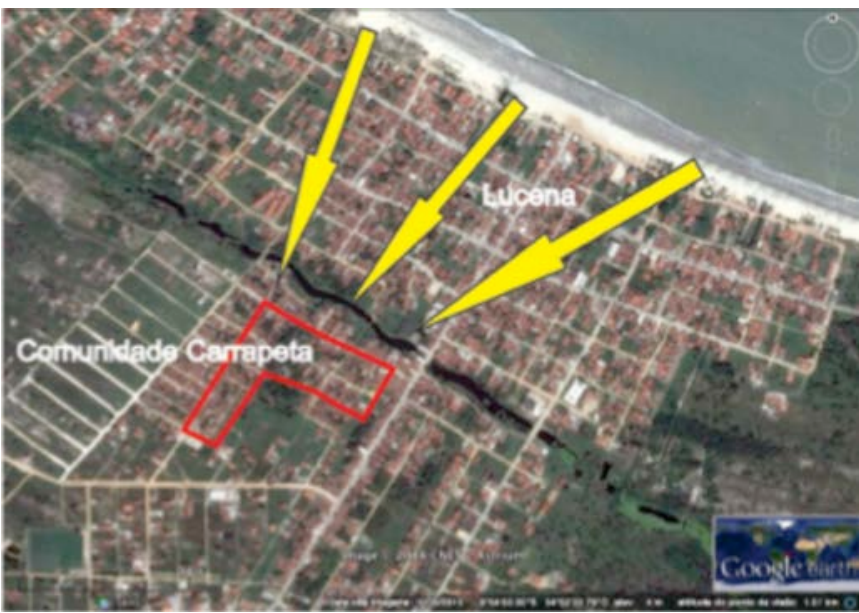

Figura 5 - Deslocamento dos pescadores da praia de Lucena para a comunidade subnormal Carrapeta, em Lucena.

Figure 5 - Movement of the fishermen of Lucena to the ghetto Carrapeta, in Lucena.

Para entender como foi o processo de relocação ao qual os pescadores da Praia de Lucena e da Praia de Tambaú foram submetidos, tanto pelo poder público como pelos capitalistas donos destas terras praianas, vejamos os depoimentos de pescadores das duas praias, como também o depoimento de um pescador da Praia da Penha, onde o processo de urbanização da área, que vem ocorrendo há alguns anos, passa a comprometer a permanência dos pescadores. Com isto, objetiva-se compreender o processo de expropriação que ocorreu no passado para os pescadores de Lucena e Tambaú, e como está ocorrendo atualmente para os pescadores da praia da Penha.
7.1. Depoimento do presidente da Colônia de Pescadores de Lucena, Severino Amâncio (53 anos), sobre a Praia de Lucena

Morei na beira da praia. Os proprietários davam um canto na beira da praia quando se pedia um pedaço de chão. Terreno de praia até à década de 1970 não tinha valor. Entre os pescadores, se dizia que quem vivia em praia era aratul. A maioria dos pescadores recebeu terreno em troca para sair da praia. Quando moravam na praia, os pescadores não tinham permissão de construir casas de alvenaria. Viviam em casas de palha e chão batido (Fig. 6).

Hoje, a pressão é sobre as caiçaras ${ }^{2}$ dos pescadores: os veranistas não querem que os pescadores façam caiçaras em frente às suas residências.

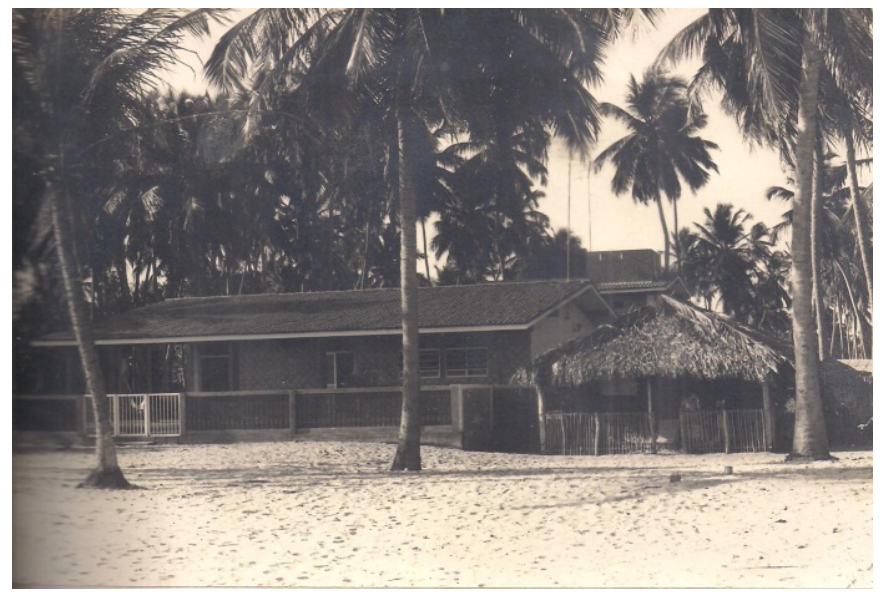

Figura 6 - Casa de palha de um pescador ao lado de uma casa de veraneio, de alvenaria, em 1980, no município de Lucena. Fonte: Ana Cornélio Madruga

Figure 6 - Straw house of a fisherman next to a summer house made of brick in 1980 in the municipality of Lucena. Source: Ana Cornélio Madruga

A pesca como atividade principal gera apenas um salário mínimo ( $\mathrm{R} \$ 678,00$ reais, o que equivale, em 13/04/2014, a \$312,44) por mês, em média. Muitos pescadores hoje já deixam de pescar para fazer outras atividades que sejam mais lucrativas. A pesca como primeira atividade só daria certo com embarcações mais apropriadas. Hoje em dia, o pescador tem medo de mandar o filho para o mar. A situação do pescador é penosa, pois é difícil de viver. Se eu pesco e tenho filho, eu não quero que ele vá para o mar. Hoje em dia, tem muitas profissões, muitas possibilidades.

\footnotetext{
${ }^{1}$ Esse caranguejo também é chamado de Maria Farinha. Tem coloração branca e amarelada, e tem como habitat as areias de praia.

2 Palhoça que serve como depósito para armazenamento de apetrechos de pesca dos pescadores. As caiçaras são construídas nas areias de praia pelos pescadores. Exemplos de petrechos de pesca são: rede, jangada, linha, anzol e canoa. Há algumas décadas, os pescadores moravam em palhoças semelhantes às caiçaras.
} 
Essa pesca que temos aí não dá para tirar mais de um salário mínimo por mês. A gente pesca, no máximo, a vinte milhas, muitas vezes em barcos pequenos, de até oito metros, para ir num dia e voltar no outro. Não temos dinheiro para melhorar nosso trabalho. $O$ governo oferece empréstimos, mas não temos como fazer empréstimos porque não temos como dar garantias, pois não temos bens.

\subsection{Depoimento do pescador Claudemar (Vavá, 62 anos), sobre a praia de Tambaú}

Tambaú começou a crescer a partir de 1955. Até aí só existiam pescadores na praia. O hotel Tambaú (Fig. 7), construido em 1978, atraiu o crescimento. A caiçara dos pescadores ficava onde fica o hotel Tambaú. Eu cheguei em 1966. Nesse ano, Tambaú já estava loteado até o que hoje é a Avenida Rui Carneiro. Essa avenida ainda não existia nessa época.

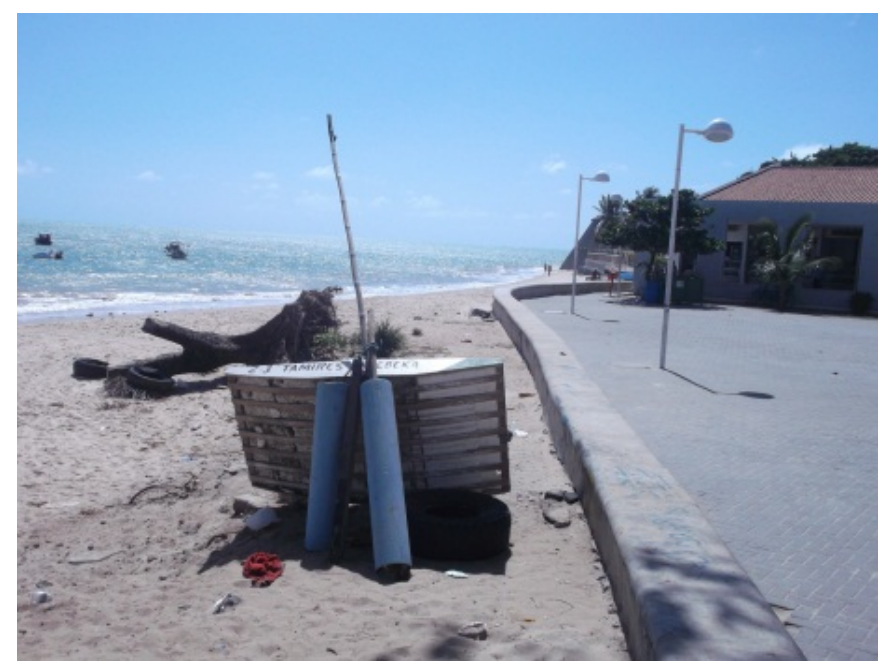

Figura 7 - Em primeiro plano, uma jangada; ao fundo, Mercado de Peixes e Hotel Tambaú.

Figure 7 - A raft and, in the background, part of the Fish Market and of the Hotel Tambaú.

Os pescadores moravam na atual Av. Franca Filho, no atual bairro de Manaíra, e na Avenida Olinda, que fica em frente ao hotel Tambaú.

Em 1967, fizeram uma Vila dos Pescadores, perto da Capital Fiat, na Avenida Rui Carneiro. Fica na Avenida Sapé. Na época, o governo fez cerca de 65 casas. Hoje, pescador na Vila, não tem mais de 10 pessoas. A maioria dos pescadores que receberam as casas morreram. Os filhos foram vendendo essas casas $e$, dos que ficaram, quase nenhum trabalha com a pesca atualmente.

Toda vida o Poder Público mudou como bem queria o lugar do pescador morar, e pescador é bicho besta, tudo aceitava. E, também, quando se dava ao pescador uma casa de alvenaria para ele deixar a de palha, quem é que não queria? O negócio do pescador mesmo é ter a beira da praia dele e um lugar para botar a família.

Hoje, a beira de praia é do turista, mas, na minha época, a beira de praia todo mundo sabia que era do pescador. Lugar de pescador é na beira da praia. Atualmente, a maioria dos pescadores mora na comunidade São José, e o restante, em bairros pobres da cidade.

Nossa caiçara está ao lado do hotel Tambaú, mas hoje eu não tenho coragem de ficar na caiçara a partir das 21 , pois é muito perigoso. A caiçara era onde ocorria o lazer do pescador. Onde ele bebia com os amigos, onde ele botava a rede e dormia quando vinha cansado do mar.

A maioria dos pescadores de hoje são os filhos dos pescadores velhos. Já os pescadores de hoje não querem seus filhos pescando. Daqui a duas gerações, praticamente não haverá mais pescador. A pescaria é incerta. Somente se o filho não quiser estudar é que ele vai virar pescador. Eu tenho um filho pescador, mas eu não queria isso para o meu filho. E tenho certeza que ele não quer isso para o filho dele.

Da minha época para hoje, já diminuiu cerca de 70\% do número de pescadores, e não está recompondo. Estão vindo pescadores de outros lugares.

\subsection{Depoimento do presidente da associação de Pescadores da Penha, José Paulino (Zeca, 46 anos), sobre a Praia da Penha}

Tem pessoas que já estão pensando em vender suas casas, porque a pesca já não tá tão boa. Pescador também está mais escasso. Hoje, o pescador também é pedreiro, pintor, trabalha na construção civil. Também tem pescador que hoje é funcionário público. Pescaria é hoje e não amanhã, e o pescador não vai deixar a família passar fome. Tem que pescar cerca de 20 dias em média por mês para lucrar um salário mínimo.

Na Penha, ainda há umas 100 famílias de pescadores. O número de pescadores vem caindo nos últimos anos.

Dá muito pouco peixe por causa da poluição e pesca predatória. $O$ mangue do Rio do Cabelo foi extinto para fazer condomínio fechado. Esse condomínio destruiu o estuário. $O$ rio chegava a $3 m$ de profundidade, na década de 1980. Era um estuário grande. Não existe mais. Os peixes precisam de estuários para se reproduzir. Os caranguejos precisam de mangues.

Onde havia um bar conhecido como Forró da Penha hoje é um restaurante que veio de outro pais. Esse restaurante já comprou três casas e certamente vai comprar mais. Essas casas eram de pessoas que não tinham vínculo com a pesca. Os bares compravam pescado aos pescadores. O restaurante compra apenas 
aos atravessadores. Muitas pessoas que moram no centro de João Pessoa passaram a conhecer a praia da Penha por causa desse restaurante. Embora a Penha seja tão perto, muitas pessoas não conheciam.

O pescador nato não pensa em sair da praia, a não ser para o cemitério. Mas quem tem a pesca como um divertimento, estes não veem problema em vender. Hoje, umas 30 famílias no Bairro da Penha vivem apenas do mar. Há umas 30 a 40 famílias que vivem entre o mar e uma atividade econômica no continente. $O$ restante tem a pesca como diversão, passatempo.

As nossas mulheres já trabalham como empregadas domésticas nos condomínios, também como babá, como também no Centro da Cidade, pela facilidade de transporte.

Como a Penha é um lugar sossegado, muitas pessoas vêm atrás de casas para morar. Às vezes, são famílias atrás de casas para usar como segunda residência, para ter uma casa na praia.

Quando vêm cursos oferecidos pelo governo, são de dois dias. Isso é muito pouco. Também ensinar o pescador a pescar é dificil, é como querer botar um bode dentro d'água. É querer ensinar um padre a rezar a missa. Isso não ajuda. A Professora Cristina Crispim vem fazendo um trabalho sério conosco, nos ensinando a não degradar a natureza. Isso nos é útil. Vem nos ensinando como repovoar de caranguejo o Rio Aratu, que é aqui próximo da Penha; vem nos ensinando a criar ostra. Mesmo assim, ainda precisamos de mais coisas, porque isso ainda não é suficiente. Quem não quer uma vida melhor? Ainda haverá pescador trabalhando na construção civil e em outras atividades.

Quanto à vinda dos condomínios fechados para o nosso redor, é bom, porque ai a gente tem mais facilidade de escoar a produção. Nosso medo é nos tirarem daqui, nos remover para longe da praia.

\section{Análise dos depoimentos dos senhores Cibil (Praia de Lucena) e Vavá (Praia de Tambaú)}

Podemos observar, nas falas dos senhores Cibil e Vavá, que o terreno de praia, tanto em Lucena como em João Pessoa, há algumas décadas, praticamente não tinha valor econômico. À medida que os terrenos começaram a se valorizar, porque passaram a surgir interessados em comprar terrenos para veraneio, num primeiro momento, e depois para moradia como primeira residência, os pescadores foram removidos da beira de praia para dentro do continente.

À medida que essas áreas, até então rurais, passaram a ser urbanas, os pescadores passaram, pouco a pouco, a perder a identidade com o ambiente de seu ofício, a praia, e depois o mar, considerando que, ao serem relocados para conjuntos habitacionais ou mesmo aglomerados de moradias subnormais (favelas), muitos pescadores passaram a exercer outros ofícios.
Nas falas de Cibil e de Vavá, também aparecem as características da moradia do pescador nesse período. Eram casas de palha, geralmente em sítios de coqueiros, onde os pescadores não tinham direito de fazer melhoramentos nas palhoças, no sentido de transformálas em casas de alvenaria, ou mesmo de taipa.

O motivo é que, mesmo naquela época, com os terrenos de praia ainda sem valor, esses terrenos já eram entendidos pelos proprietários como reserva de mercado, como também a terra, no Brasil, historicamente, serve para perpetuar poder nas mãos de seus donos, que passam a ter o controle social dos moradores.

O processo de remoção dos pescadores dos ambientes de praia foi tão marcante nas praias de Lucena e Tambaú que Cibil relata que os veranistas em Lucena não querem que uma caiçara seja construída em frente às casas de veraneio; enquanto que em Tambaú o pescador Vavá diz, de forma saudosa, que a praia era do pescador, mas hoje a praia é do turista.

Cibil e Vavá também comentam sobre a relação do Estado com os pescadores. Ambos expressam que as ações do Estado, historicamente, não beneficiam os pescadores. Até hoje, o Estado não procurou garantir o território tradicional de pesca, o que se verifica nas relocações e na dispersão dos pescadores, que o Poder Público participou de forma ativa ou passiva.

Com relação à permanência dos trabalhadores da pesca artesanal nessa atividade, o Estado também não tem criado mecanismos efetivos para que o pescador possa se adequar às novas exigências da atividade, tão penalizada pela poluição, falta de capacitação adequada e efetiva e falta de subsídios que verdadeiramente contribuam para a melhoria na qualidade de vida do pescador, ou mesmo a falta de acesso aos subsídios, pois o pescador não tem o que dar de garantia para ter direito aos empréstimos.

Por causa de todas essas dificuldades dos pescadores, que deixaram de ser e viver em ambientes rurais para serem e viverem em ambientes urbanos, dispersos e emersos nas possibilidades de trabalho e estudos no espaço urbano, Cibil e Vavá deixam claro que não querem que seus filhos e netos sejam pescadores, pois o que ganham com a pesca durante um mês de trabalho dificilmente passa de um salário mínimo. Como diz Cibil, o mar é perigoso. Como diz Vavá, o trabalho do pescador é muito difícil. Sendo assim, a cidade passa a propiciar o emprego desta mão de obra em outras atividades econômicas, escasseando cada vez mais o número de pescadores.

\section{Análise do depoimento do senhor Zeca}

Observamos quase todos os mesmos aspectos de precariedade do trabalho e da vida do pescador na comunidade de pescadores tradicionais da Penha: baixa 
renda, destruição do estuário e do manguezal para dar lugar a moradias de alto padrão, poluição do mar e pesca predatória.

Quanto à chegada de condomínios de alto padrão e hotéis nos arredores da Praia da Penha, os pescadores veem esse tipo de urbanização esperançosos de venderem por preços melhores o pescado, mas, como historicamente as comunidades de pesca são relocadas, eles têm receio de serem expulsos da praia por algum governo que queira favorecer grupos econômicos do ramo hoteleiro.

Todavia, o que vem ocorrendo, de fato, é a compra de imóveis na comunidade de pescadores pelo capital comercial e por pessoas que não possuem dinheiro suficiente para comprar uma casa em um condomínio fechado, mas que têm interesse de ter uma moradia em ambiente de praia.

Isso ocorre porque há muito mais dinheiro circulando em João Pessoa atualmente do que há quatro décadas. E a Praia da Penha se tornou um enclave de possibilidades de aquisição de imóvel relativamente barato em uma faixa de praia onde os terrenos estão muito valorizados, por estar na zona turística delimitada no Plano Diretor do município de João Pessoa.

Assim, o capital vem se reinventando, e as comunidades excluídas passam a sofrer pressão tanto do capital como do Estado capitalista, como também omissão deste, que não busca desenvolver políticas públicas que contribuam efetivamente para que comunidades tradicionais se mantenham em espaços que passam a se valorizar economicamente.

O pescador que atualmente reside na Penha é um pescador diferenciado em relação ao que ali habitava há 40 anos, pois esse pescador é urbano, ou seja, tem acesso a informação e também tem proximidade de bens e serviços que deseja consumir, considerando que vive em uma sociedade burocrática de consumo dirigido, como afirma Henri Lefebvre (1991).

Isso implica em o pescador começar a exercer outras atividades produtivas em detrimento da pesca, visto que pescar é considerado por eles um trabalho penoso e que não rende mais de um salário mínimo por mês. Assim, o pescador passa a desejar bens e serviços que ele não pode adquirir com a atividade pesqueira, por render pouco e também por esta renda ser incerta.

A implicação direta disso é a diminuição do número de pescadores, que preferem receber até mais de um salário mínimo em atividades urbanas relacionadas à construção civil, como também a prestação de serviços nos condomínios, como vigilante, jardineiro, caseiro etc. As mulheres desses pescadores também deixam de se ocupar em atividades relacionadas com a pesca, passando a desempenhar serviços de babá, diarista, empregada doméstica, dentre outras atividades.
Discutir o processo de reordenamento urbano na Praia da Penha e seus arredores compreende, antes de mais nada, discutir desenvolvimento sustentável em sua essência, pois surge uma questão: como garantir que o planejamento, numa perspectiva de desenvolvimento sustentável, acompanhe a velocidade do avanço imobiliário, no sentido de garantir a permanência e a manutenção de uma comunidade tradicional, de forma a estar inter-relacionada com esse processo, e não apenas ser marginalizada e retirada pela força e complexidade do capital imobiliário em suas múltiplas dimensões?

\section{Depoimentos de pescadores que coordenam pescadores}

\subsection{Depoimento do Armador ${ }^{1}$ de Pesca Iran (59 anos)}

Tenho um barco e pesco há mais de 40 anos. Nos últimos anos, vem diminuindo o número de pescadores. Os pais não querem que seus filhos pesquem. Antigamente, os pescadores eram donos da praia. A especulação imobiliária foi retirando os pescadores da praia.

É mais vantagem o pescador ter sua mulher trabalhando de doméstica e ele trabalhando de vigia do que passar quatro dias por semana no mar. Escolhemos a equipe do barco pela relação de confiança. $90 \%$ dos pescadores moram na favela São José.

Aqui, em Tambaú, há cerca de 30 barcos (Fig. 8), e em cada um trabalham 03 pescadores. $O$ mestre ${ }^{2}$ de pesca e dois ajudantes, geralmente profissionais da pesca. A nossa caiçara, que é o lugar onde os pescadores colocam petrechos, já foi relocada várias vezes para partes diferentes da praia!

Nós não somos vistos como prioridade pelos governos. Nossa caiçara não tem nem banheiro e não dá mais para fazer necessidade aqui pela beira da praia, pois esta praia já está totalmente ocupada por casas, prédios e pessoas. Fui secretário da colônia - todo mundo acha que a pesca é de um jeito, mas a pesca é de outro.

A pesca é desorganizada, pois não há controle efetivo dos órgãos federais e estaduais responsáveis. Há pessoas que se beneficiam dessa falta de controle estatal e do analfabetismo do pescador. Isso também contribui para o quadro de desorganização do setor

\footnotetext{
1 Armador de pesca é a pessoa física ou jurídica que, registrada e licenciada pelas autoridades competentes, apresta, em seu nome ou sob sua responsabilidade, embarcação para ser utilizada na atividade pesqueira, pondo-a ou não a operar por sua conta (Lei Federal 11.959/2009).

${ }^{2} \mathrm{O}$ mestre é o capitão de pesca. Por isso é a pessoa que possui autoridade frente aos outros pescadores por ser ele a pessoa que detém mais conhecimentos e os segredos da pesca. O mestre faz a mediação tecnológica entre a terra e o mar (Maldonado, 1993; Diegues, 1983; Forman, 1970).
} 
pesqueiro artesanal do Brasil. Recursos federais são investidos, mas são mal administrados. A cada ano que passa, diminui a quantidade de peixes. Como vai organizar uma categoria em que os trabalhadores são analfabetos?

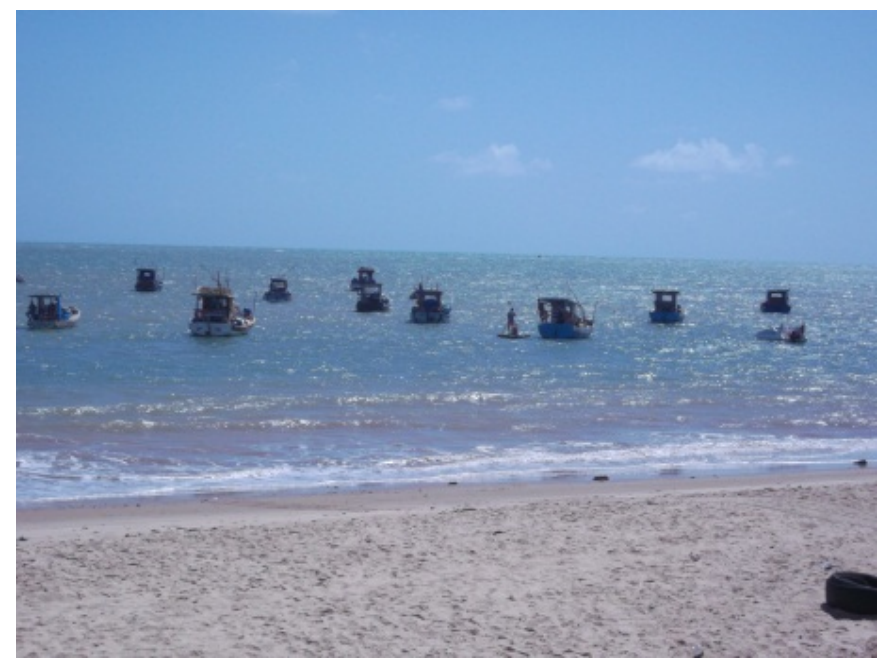

Figura 8 - Botes ancorados em Tambaú.

Figure 8 - Boats anchored in Tambaú

\subsection{Depoimento do mestre de pesca Manuel (67 anos)}

Aqui, em Tambaú, há uns 40 anos, havia uns 60 profissionais de pesca que sabiam fazer tudo, desde lidar com os petrechos de pesca, como também localizar os melhores lugares de pesca no mar. Esses são os Mestres, comandantes dos botes. $O$ mestre tem que saber de tudo, de proa a polpa da embarcação. Havia cerca de 120 ajudantes muito bons.

Hoje, tem muitos pescadores "pega na rua", ou seja, sem qualificação para trabalhar no mar. Os jovens de hoje não sabem amarrar um anzol, ancorar o barco para pescar ou mesmo trabalhar com outros acessórios de pesca. Nossos barcos são compostos de tripulação formada pelo Mestre e mais dois ajudantes. Tá dificil arrumar gente qualificada para ajudar. Atualmente, só há cerca de 20 Mestres aqui em Tambaú.

Ainda moro aqui em Tambaú, na Avenida Olinda, e não tenho interesse de sair daqui. Esse terreno é da família (Fig. 9). Minha mãe ainda é viva, tem 83 anos. Eu sou o mais velho. Tem seis casas aqui nesse terreno e todos são familiares. Há muitos construtores querendo comprar nosso terreno. E não queremos vender. Se sairmos daqui, vamos para a favela, e você sabe o que tem na favela: muita droga e violência.

Meu pai era pescador e teve quatro filhos. Desses quatro filhos, três são pescadores. Eu tenho dois filhos

\footnotetext{
${ }^{1}$ Pega na rua é uma expressão idiomática brasileira que significa: pessoa sem qualificação; pessoa sem condições para desempenhar uma determinada função ou atividade.
}

e um é pescador. Com relação aos meus outros dois irmãos que são pescadores, um tem um filho que não é pescador e o outro tem dois filhos que também não são pescadores. $O$ pescador não quer que seu filho siga essa profissão.

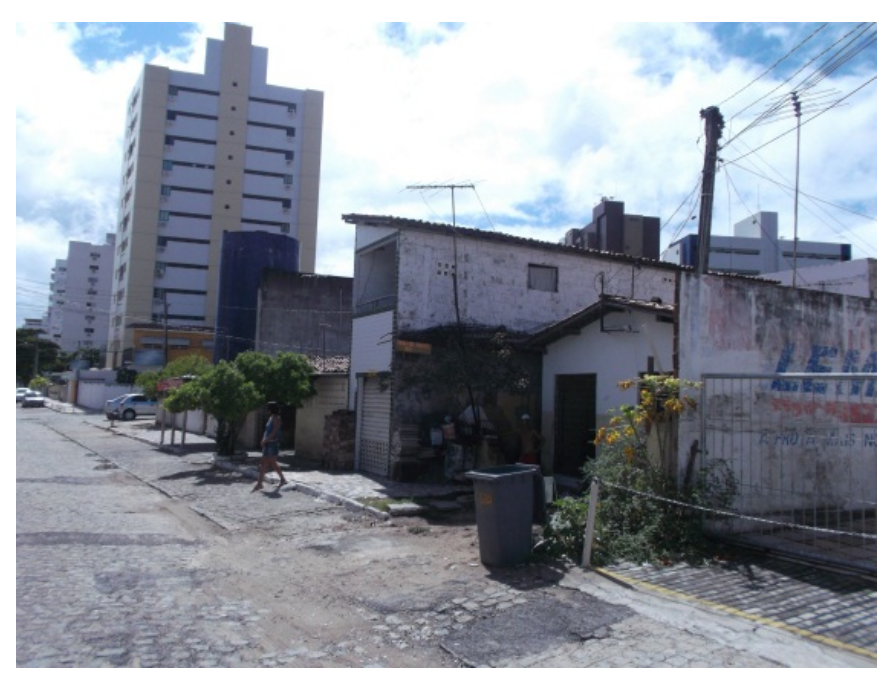

Figura 9 - Uma moradia com primeiro andar e uma térreo, ambos de baixo padrão econômico, no terreno da família do Mestre de Pesca Manuel, na Avenida Olinda, no bairro de Tambaú.

Figure 9 - A loft and a house, both of them below the economic standard, at Master Fisher Manuel family's property, on Olinda Avenue, in Tambaú.

\section{Análise dos depoimentos dos senhores Iran e Manuel}

$\mathrm{O}$ armador de pesca Iran e o mestre de pesca Manuel também salientam a diminuição do número de pescadores nas últimas décadas. Deixa claro que os pescadores não querem que seus filhos trabalhem na pesca e que não há organização nessa atividade econômica em todos os níveis de produção e também governamentais relacionados. Eles também salientam que os pescadores apenas possuem condições financeiras para morar em favelas.

Iran salienta a dificuldade de se organizar uma atividade produtiva composta por analfabetos e semianalfabetos, além de destacar o fato de a atividade pesqueira tradicional não ser vista como prioridade pelo governo, como também os trabalhadores nela envolvidos.

O mestre Manuel chega a fornecer dados a partir de sua memória quanto à diminuição da quantidade de mestres de pesca nos últimos 40 anos. Segundo Manuel, a queda no número desses profissionais é de $66 \%$.

No bojo do processo de urbanização de Tambaú, que teve como uma de suas consequências a diminuição do número de pescadores profissionais, mestres ou ajudantes, podemos perceber esse decréscimo no número de pescadores na árvore genealógica da família 
do senhor Manuel, onde seu pai gerou quatro filhos, dos quais três são pescadores. Todavia, dos cinco netos do pai do mestre Manuel, filhos dos três irmãos que são pescadores, apenas um é pescador.

A permanência do mestre Manuel na Avenida Olinda, atualmente com o metro quadrado supervalorizado, se dá por questões de laços parentais. $O$ desejo de a família permanecer unida é bem maior do que um possível interesse em vender o terreno e dividir o dinheiro entre os familiares. É perceptível, também, a consciência da perda na qualidade de vida se venderem o terreno, pois dali sairiam para um conjunto habitacional periférico ou para uma favela. $O$ que não é da vontade da mãe de seu Manuel e nem dos três irmãos que são pescadores.

\section{Conclusões}

A discussão sobre desenvolvimento passa pela questão do direito a permanecer residindo no lugar de vida e trabalho dos ancestrais, mesmo que esteja ocorrendo uma migração da força de trabalho tradicional para outras atividades econômicas. Discutir desenvolvimento também é tratar sobre onde morar, o que implica em onde viver e trabalhar.

O urbano não deve cercear a permanência das comunidades tradicionais em seus lugares. $\mathrm{O}$ urbano traz problemas e conflitos de todos os vieses sociais, econômicos e culturais, mas também traz possibilidades que precisam ser postas em discussão e análise. Daí a necessidade de se analisar o pescador artesanal também pelo viés da moradia.

Portanto, para discutir desenvolvimento, partamos do seguinte pressuposto: o desenvolvimento é um conceito multidimensional. Os seus objetivos são sempre sociais e éticos (solidariedade sincrônica). Ele contém uma condicionalidade ambiental explícita (solidariedade diacrônica com as gerações futuras); o crescimento econômico, embora necessário, tem um valor apenas instrumental; o desenvolvimento não pode ocorrer sem crescimento, no entanto, o crescimento não garante por si só o desenvolvimento; o crescimento pode, da mesma forma, estimular o mau desenvolvimento, processo no qual o crescimento do PIB é acompanhado de desigualdades sociais, desemprego e pobreza crescente (Sachs, 2008), além de remoção de comunidades tradicionais, o que deve ser evitado.

Quem está interessado numa "economia de desenvolvimento" deve investir no ser humano e na sociedade. Quem quer ver os frutos da prosperidade econômica deve se preocupar mais com isso. Para atingir desenvolvimento social, é preciso mudar padrões de comportamento social que são estabelecidos a partir do "corpo" e do "metabolismo" das sociedades, vistas como sistemas complexos compostos por agentes que interagem em termos de competição e cooperação. Por isso, Desenvolvimento Local Integrado Sustentável é um programa político, uma estratégia política de empoderamento das comunidades, uma tecnologia social (Franco, 2002).

No tocante à interação de diferentes interesses e modos de trabalho e vida em espaços urbanos, a reflexão sobre a cidade deve ser concebida como sistema urbanosocial-ambiental, porque a cidade é um sistema no qual cada indivíduo ou grupo social, cada rua ou bairro é interdependente do todo, e seu funcionamento depende de estratégias comuns, devendo ser discutidas e negociadas num processo político-social. A visão não sistêmica ou fragmentada da cidade não isola apenas os cidadãos e os grupos sociais entre si, mas também distorce a visão das causas das atividades humanas que produzem impacto socioambiental na cidade e nos cidadãos.

Tal impacto tende a ser visto como um problema anônimo, acidental, extra-social e próprio da cidade. Também é visto como um problema pertencente sempre ao outro eu-parte do sistema urbano-social-ambiental (Menegat \& Almeida, 2004). E essas formas fragmentadas de pensar geram métodos fragmentados de agir, o que implica em ciclos viciosos de atraso e marginalização de comunidades tradicionais.

Em 2009, foi promulgada a Lei $n^{0} 11.959 / 2009$, que dispõe sobre o Plano Nacional de Desenvolvimento Sustentável da Aquicultura e Pesca. O art. $7^{\circ}$ dessa lei fala em proteger áreas pesqueiras, mas não diz como fazer. Mesmo que dissesse, o que seria um grande avanço na política pesqueira, isso só asseguraria locais aquáticos passíveis de ocorrência de recursos pesqueiros.

Recursos pesqueiros são os animais e os vegetais hidróbios passíveis de exploração, estudo ou pesquisa, como também pela pesca amadora, de subsistência, científica, comercial e pela aquicultura, o que não implicaria na manutenção das comunidades tradicionais na orla marítima, ou seja, em seus lugares historicamente construídos.

A Organização Não-Governamental Caritas Brasileira, ligada à igreja Católica, vem articulando a discussão sobre demarcação das terras das comunidades de pescadores, a fim de que essas não sejam esbulhadas pelo capital imobiliário, pela ação negativa do Estado sobre essas comunidades e pela omissão deste. Esse processo está ainda na fase de mobilização de pessoas e instituições, inclusive estaduais e federais de educação.

A Cáritas Brasileira tem mobilizado pescadores e pescadoras do Brasil. Com relação a essa temática, objetiva arrecadar até 2015 mais de 1 milhão de assinaturas para um projeto de lei que vise regularizar os territórios dessas comunidades tradicionais. Para articular e mobilizar os pescadores e as pescadoras, foram realizadas caravanas pelas regiões do Brasil. Os militantes que compõem as equipes das caravanas buscam informar e mobilizar comunidades pesqueiras, com a finalidade de articular e organizar os pescadores 
e as pescadoras para empoderá-los dos seus direitos de identidade cultural, de pesca, de moradia e de ir e vir, enfrentando os desafios de permanecer em seus territórios.

Um dos grandes desafios da demarcação é não gerar leis que prejudiquem uma determinada região ou localidade, como vem acontecendo em alguns casos relacionados às comunidades quilombolas e indígenas, quando a normatização da terra comunal e a desintrusão tem gerado vários problemas econômicos e sociais, tanto para esses povos como para empreendedores, além de grupos econômicos de investidores.

Uma questão deve, então, ser levantada na discussão da demarcação: como a comunidade tradicional está se relacionando com o município e como, historicamente, os capitalistas se relacionam com essas comunidades? $\mathrm{O}$ tratamento das questões municipais deve ocorrer à luz da gestão sustentável de dimensão municipal e de forma integrada, tendo em vista estratégias de produtividade para as diferentes localidades municipais, com a valorização das manifestações culturais, o que tende a aumentar a autoestima dos sujeitos locais e contribuir para a geração de emprego e renda, equidade no acesso aos serviços públicos e a realização da justiça ambiental e social, tendo em vista a complexidade cultural de um município metropolitano, como é o caso de João Pessoa e Lucena.

Destacando o artigo $5^{\circ}$ da Constituição Federal Brasileira, que trata dos direitos e deveres individuais e coletivos, incisos XXII e XXIII, nos quais é garantido o direito à propriedade, mas esta deve cumprir sua função social, ou seja, não apenas servir a interesses particulares, mas em consonância com os interesses coletivos a partir do diálogo entre a prefeitura municipal, demais poderes e a sociedade, através de estudos técnicos desenvolvidos pela prefeitura e propostas elaboradas pela comunidade e, também, de forma articulada, as comunidades e grupos de interesse do entorno.

Essa relação entre Poder Público e participação comunitária significa um avanço no sistema democrático representativo do Brasil, em que apenas os estudos técnicos não bastam, mas se faz necessário escutar os munícipes e dialogar com eles em seminários temáticos nos quais se discutem os problemas e as soluções para os próximos anos, com metas para cerca de dez anos, como propõe o Estatuto das Cidades (Lei $\mathrm{n}^{\circ}$ 10.257/2001).

Devido à sua capacidade de organização e operacionalização, o município possui condições de enfrentar a problemática do desenvolvimento, pois é parte planejadora e operante do Estado na dimensão local, devendo contar com sua população para dialogar sobre suas necessidades básicas e criadas. Desta feita, é no âmbito municipal que se pode, de forma sistêmica e sistematica, formar a sociedade para o desenvolvimento susten- tável, pois seus munícipes conhecem, de forma cotidiana, os problemas municipais e, de maneira mais prática, também têm condições de tecer melhores comentários sobre possíveis soluções.

O município carece de planejamento participativo, empoderamento e fiscalização popular, instrumentos que disciplinem a sua expansão urbana, sua estrutura fundiária e pressão sobre a natureza, levando em consideração os aspectos culturais locais, as limitações ambientais e o controle do mercado imobiliário, ao mesmo tempo em que carece de uma gestão voltada para a convergência das diferentes atividades produtivas, potencializando-as e contribuindo para que tenham eficácia.

Assim, o que se quer propor são estratégias de complementaridade entre os diferentes grupos e classes que habitam o lugar, ou seja, estratégias voltadas ao desenvolvimento humano, preservação ambiental e empoderamento comunitário, o que tende a contribuir no processo de interação e integração entre os diferentes interesses econômicos em um determinado espaço.

Isso implica em reconhecer e desenvolver formas que atenuem as desigualdades sociais e o convívio entre grupos sociais e econômicos, que certamente continuarão em eterna disputa por causa do modelo econômico, mas não necessariamente que um venha sucumbir frente ao outro.

O Decreto Federal $n^{\circ} 6.040 / 2007$, que institui a Política Nacional de Desenvolvimento Sustentável dos Povos e Comunidades Tradicionais, deixa claro, em um de seus princípios, que, mesmo em um espaço urbano, os direitos de uma comunidade tradicional de permanecer no lugar devem ser mantidos.

Assim, diz este documento legal que a pluralidade socioambiental, econômica e cultural das comunidades e dos povos tradicionais que interagem nos diferentes biomas e ecossistemas, seja em áreas rurais ou urbanas, é princípio que deve contribuir na condução do planejamento de um determinado espaço. Isso tende a contribuir para o reconhecimento e a consolidação dos direitos dos povos e das comunidades tradicionais, que é outro princípio do decreto supracitado.

Outro princípio do referido decreto que aqui deve ser mencionado é o da preservação dos direitos culturais, o exercício de práticas comunitárias, a memória cultural e a identidade. Sabe-se que muitas comunidades tradicionais estão em intensa transformação em suas manifestações culturais, por serem espaços em que os sujeitos passam a desempenhar atividades urbanas, e a pesca começa a deixar de ser uma atividade econômica procurada e exercida pelos moradores do lugar.

Todavia, é justamente nas manifestações culturais materiais e imateriais da pesca que essa atividade pode ainda perdurar, considerando que muitas pessoas, principalmente turistas, amantes dos passeios náuticos 
ou pescadores amadores, podem pagar para contemplar o modo de trabalho e vida do pescador artesanal, que deveria ser em espaço considerado historicamente de comunidade tradicional, para fins de construção de equipamento público ou construção/melhorias de moradia para outras famílias de pescadores, garantindo que o espaço permaneça ocupado por famílias que se relacionam com as atividades pesqueiras.

Outros instrumentos de valorização da comunidade tradicional em espaço urbano também podem ser considerados, como, por exemplo, a inserção, de maneira obrigatória, nos relatórios antrópicos para licenças ambientais de grandes empreendimentos, de modo que sejam levadas em consideração suas formas de participação na cadeia produtiva, e como tal empreendimento pode interagir economicamente com a comunidade tradicional, propondo a criação de parcerias.

As comunidades de pescadores localizadas em áreas urbanas devem ser entendidas como espaços turísticos, o que demanda atenção especial dos Ministérios do Turismo, Ministério da Pesca, Ministério do Meio Ambiente; Ministério do Planejamento; Ministério do Desenvolvimento Social, entre outros.

A valorização do patrimônio cultural material e imaterial como indutor para sociedades sustentáveis deve observar a construção de inventários culturais, que podem ser convertidos em poderosos instrumentos de análise urbana e municipal de forma sistêmica (Rolnik \& Pinheiro, 2008), beneficiando essas comunidades e contribuindo para o aumento da renda familiar, como também sinalizando onde devem ser construídos equipamentos urbanos como mercado de peixe, espaço cultural da pesca e da vida marinha etc. que venham contribuir para a visibilidade da comunidade tradicional, sendo entendida com um espaço que deve fazer parceria com os ambientes ao redor, deixando de ser vista apenas como uma área a ser removida, como historicamente tem ocorrido.

\section{Referências bibliográficas}

Corrêa, Roberto Lobato (2002) - O espaço urbano. 96p, Ed. Ática, São Paulo, SP, Brasil. ISBN: 85-08032609.

Diegues, Antônio Carlos (1983) - Pescadores, camponeses a trabalhadores do mar. 287p, Ática, São Paulo, Brasil. Disponivel em: http://nupaub.fflch.usp.br/sites/nupaub.fflch. usp.br/files/color/prof 4.pdf

Franco, Augusto de (2002) - Pobreza e desenvolvimento local. 336p, ARCA sociedade do conhecimento, Brasília, DF, Brasil. ISBN: 85-88699036.

Forman, Shepard (1970) - The raft fisherman. 158p, Bloomington, Indiana University Press, Bloomington, IN, U.S.A. ISBN: 25339201-2.

Gerhardt, Tatiana Engel; Silveira, Denise Tolfo (org) (2009) Métodos de pesquisa. Universidade Aberta do Brasil, Secretaria de Educação a Distância, Editora da UFRGS, Porto Alegre, RS, Brasil. ISBN 978-8538600718

Harvey, David (2005) - A produção capitalista do espaço. 252p. Annablume, São Paulo, SP, Brasil. ISBN: 8574194964.

Lackey, Robert Thomas; Nielsen, Larry (orgs.) (1980) - Fisheries Management. 422p. Blackwell, Oxford, U.K. ISBN: 0632006153.

Lefebvre, Henry (1991) - A vida cotidiana no mundo moderno. 216p., Ática, São Paulo, SP, Brasil. ISBN: 8508037929.

Lefebvre, Henry (1999) - A revolução urbana. 178p., Ed. UFMG, Belo Horizonte, MG, Brasil. ISBN: 8570411952.

Lefebvre, Henry (2001) - $O$ direito à cidade. 145p., Centauro, São Paulo, SP, Brasil. ISBN: 8588208121.

Marx, Karl (1996) - O Capital. Crítica da Economia Política. O Processo de Produção do Capital. 482p., Livro Primeiro, Tomo 1, Editora Nova Cultural, São Paulo, Brasil. ISBN: 8535108319.

Mathiesen, Árni (Org.) (2012) - El estado mundial de la pesca y la acuicultura. 231p., Departamento de Pesca y Acuicultura de la Organización de las Naciones Unidas para la Alimentación y la Agricultura, Roma, Itália. ISBN: 978-9253072255. Disponível on-line em: http://www.fao.org/docrep/016/i2727s/i2727s.pdf

Maldonado, Simone Carneiro (1993) - Espaço e indivisão na pesca maritima. 194p., Annablume, São Paulo, SP, Brasil. ISBN: 8585596082 .
Menegat, Rualdo; Almeida, Gerson (2004) - Sustentabilidade, democracia e gestão ambiental urbana. In: Rualdo Menegat (org.), Desenvolvimento Sustentável e Gestão Ambiental nas Cidades: estratégias a partir de Porto Alegre, pp.171-194, Editora da UFRGS, Porto Alegre, RS, Brasil. ISBN: 857025766X.

Secretaria Nacional de Renda de Cidadania (2012) - Guia de cadastramento de grupos: populacionais, tradicionais e especificos: cadastro único para programas sociais. 101p., Ministério do Desenvolvimento Social e Combate à Fome; Secretaria Nacional de Renda de Cidadania, Brasília, DF, Brasil.

Ojima, Ricardo (2007) - Dimensões da urbanização dispersa e uma proposta metodológica para estudos comparativos. Revista brasileira de estudos populacionais (ISSN: 0102-3098), 24(2):277-300, São Paulo, SP, Brasil. . Disponível on-line em http://www.scielo.br/pdf/rbepop/v24n2/06.pdf

Rolnik, Raquel; Pinheiro, Otilie Macedo (Orgs.) (2004) - Plano diretor participativo: guia para elaboração pelos Municípios e cidadãos. 160p., Conselho Federal de Engenharia, Arquitetura e Agronomia, Ministério das Cidades, Brasília, DF, Brasil. Disponível on-line em http://www.sehac.ms.gov.br/controle/ ShowFile.php?id=151304.

Sachs, Ignacy (2008) - Desenvolvimento: includente, sustentável, sustentado. 151p., Garamond, Rio de Janeiro, RJ, Brasil. ISBN: 85761704X.

Santos, Milton (1985) - Espaço e Método. 88p., Nobel, São Paulo, SP, Brasil. ISBN: 8521302940.

Santos, Milton (2008) - A urbanização brasileira. 176p., 5a ed., Universidade de São Paulo, São Paulo, SP, Brasil. ISBN: 9788531408601.

Taylor, S.J.; Bogdan, R. (2008) - La Entrevista em Profundad. In: Métodos Quantitativos Aplicados 2, pp.100-132, Centro de Investigación e Docencia, Secretaría de Educación y Cultura de Chihuahua, Chihuahua, $\mathrm{CHH}$, México. Disponível on-line em http://ulloavision.org/archivos/antologias/meto2.pdf.

Urbistondo, José Antônio Alarcón (2001) - Inventario de la Pesca Artesanal en España Mediterránea (2000-2001). 45p., Centro Oceanográfico, Málaga, Espanha. Disponível on-line em http://www.faocopemed.org/old_copemed/en/activ/research/artf sh.htm 


\section{Legislação}

Constituição da República Federativa do Brasil de 1988. Publicada no Diário Oficial da União de 05 de outubro de 1988. Disponível on-line em http://www.planalto.gov.br/ccivil 03/ constituicao/caonstituicao.htm

Decreto $N^{o}$ 6.040, de 07 de fevereiro de 2007. Institui a política nacional de desenvolvimento sustentável dos povos e comunidades tradicionais. Disponível on-line em http://www.planalto. gov.br/ccivil_03/_ato2007-2010/2007/decreto/d6040.htm

Lei Federal $N^{\circ} 11.959$, de 29 de julho de 2009. Dispõe sobre a Política Nacional de Desenvolvimento Sustentável da
Aquicultura e da Pesca, regula as atividades pesqueiras, revoga a Lei $\mathrm{n}^{0} 7.679$, de 23 de novembro de 1988, e dispositivos do Decreto-Lei $\mathrm{n}^{\circ} 221$, de 28 de fevereiro de 1967, e dá outras providências. Disponível on-line em http://www.planalto. gov.br/ccivil_03/_ato2007-2010/2009/Lei/L11959.htm

Lei Federal $N^{o}$ 10.257, de 10 de julho de 2001. Regulamenta os artigos. 182 e 183 da Constituição Federal, estabelece diretrizes gerais da política urbana e dá outras providências. Disponível on-line em http://www.planalto.gov.br/ccivil_03/leis/LEIS_2001/ L10257.htm. 